\title{
Responses of phytoplankton functional groups to environmental factors in the Maixi River, southwest China
}

\author{
Guojia HUANG, ${ }^{1,2}$ Qiuhua LI, ${ }^{1 *}$ Xiaoqing WANG,${ }^{2}$ Mengshu HAN, ${ }^{1}$ Lei LI, ${ }^{1}$ Jing XIAO, ${ }^{1}$ Yipeng LIU ${ }^{2}$ \\ ${ }^{1}$ Key Laboratory for Information System of Mountainous Area and Protection of Ecological Environment of Guizhou Province, \\ Guizhou Normal University, Guiyang; ${ }^{2}$ College of Animal Science and Technology, Hunan Agricultural University, Changsha, China \\ *Corresponding author: qiuhua2002@126.com
}

\begin{abstract}
The functional groups approach is an efficient way to analyze seasonal changes in phytoplankton biomass as it is based on the physiological, morphological, and ecological attributes of the species. In this study, we identified the functional groups and driving factors behind short-term succession in phytoplankton communities. We analyzed physical, chemical, and biological factors of the Maixi River in Baihua Reservoir (BHR) from August to September, 2013 (summer, phase I) and March to May, 2014 (late spring and early summer, phase II). The 226 samples collected were divided into 23 functional groups. In phase I, phytoplankton biomass ranged from 4.88 to $30.59 \mathrm{mg} \cdot \mathrm{L}^{-1}$, and the group S1 (Pseudanabaena limnetica) had the greatest biomass. In phase II, phytoplankton biomass ranged from 2.22 to $50.61 \mathrm{mg} \cdot \mathrm{L}^{-1}$, and groups $\mathrm{Y}$ (Cryptomonas sp.) and S1 (P. limnetica) had the greatest biomass. Dominant functional groups in the Maixi River changed from S1 + D + Y + Lo in phase I to Y + S1 in summer. Changes in the phytoplankton community varied between 0 and 0.144 day $^{-1}$ in phase I and between 0.008 and 0.389 day $^{-1}$ in later spring and early summer. This showed a steady-state phytoplankton community during the two phases, in which the functional groups $\mathrm{S} 1(P$. limnetica) and Y (Cryptomonas sp.) were dominant. Pseudanabaena limnetica, Synedra sp., Peridinium sp., and Cryptomonas sp. were dominant during summer, contributing to $70 \%$ of the total biomass in the steady-state community, and $P$. limnetica, Synedra sp., Cryptomonas sp., and Chlamydomonas sp. were dominant during later spring and early summer, contributing to $60 \%$ of the total biomass in the community. Groups S1, D, and Y formed easily in the Maixi River, but $P$. limnetica was the dominant species in the eutrophic conditions of the Maixi River. According to biotic and abiotic factors, we concluded that the Maixi River is hypertrophic, and water resource management should take blooms of $P$. limnetica occurring in May into account. Temperature and dissolved oxygen were the critical factors affecting the steady-state of the phytoplankton community in late spring and early summer and summer, respectively. Because the Maixi River is an important source in the BHR, its phytoplankton functional groups directly affect the ecological balance of the water environment.
\end{abstract}

Key words: Phytoplankton functional groups; short-term succession; steady-state; rate of change; Maixi River; Baihua Reservoir.

Received: December 2016. Accepted: July 2017.

\section{INTRODUCTION}

Phytoplankton is usually the primary producer in aquatic habitats, and its community composition and populations respond directly and rapidly to changes in the environment (Reynolds, 2006). Density and specific composition reorganization of the phytoplankton community are responses to the interactive processes of physical, chemical, and biological variables (Crossetti and Bicudo, 2008a). An approach to studying phytoplankton communities is by defining phytoplankton functional groups, which are based on phytoplankton ecological characteristics and growth strategies (Reynolds et al., 2002). Functional groups include species that have similar physiology, morphology, and ecology, and frequently coexist. Moreover, functional groups share similar tolerances and sensitivities (Salmaso et al., 2015) and, at present, 38 functional groups are described using alphanumerical codes (Padisák et al., 2009). Compared to phylogenetic groups, functional groups are more effective in evaluating the phytoplankton responses to changes in environmental conditions (Kruk et al., 2002). The phytoplankton functional groups approach has also been applied to reservoirs (Nixdorf et al., 2003; Naselli-Flores and Barone, 2003; Crossetti and Bicudo, 2005; Fonseca and Bicudo, 2008; Crossetti and Bicudo, 2008b; Becker et al., 2009; Xiao et al., 2011), estuaries (Smayda and Reynolds, 2003; Anderson and Rengefors, 2006; Costa et al., 2009), lakes (Kruk et al., 2002; Mieleitner et al., 2008), and subtropical coastal system (Bonilla et al., 2005).

Human activities have increased the nitrogen and phosphorus loads into water, accelerating eutrophication, and affecting the biological organization (Howarth, 1998). Phytoplankton growth and density can determine the potential productivity of the entire ecosystem (Wissel and Fry, 2005), by responding quickly to changes in the aquatic environment and indicating when physical, chem- 
ical, or biological changes occur in the water column (Reynolds, 2006). Succession is the temporal change in the phytoplankton community and ecosystem, and a "steady-state phytoplankton community" is likely to appear in a period of relatively stable environmental factors. The definition of "steady-state" has been disputed: some researchers suggested that total biomass should allow a deviation of $\pm 15 \%$ (Mischke and Nixdorf, 2003); others suggested that dominant species should represent at least $50-80 \%$ of the total abundance, and that the steady-state period should last at least two weeks (Dokulil and Teubner, 2003; Morabito et al., 2003). The steady-state concept of succession emerged in phytoplankton ecology to explain the diversity-disturbance relationship (NaselliFlores et al., 2003). Establishing equilibrium requires consideration of many different factors, such as water depth, stratification, spatial heterogeneity, disturbance, stress, and the morphological and physiological plasticity of phytoplankton species (Naselli-Flores et al., 2003). Padisák (2003) studied 80 Hungarian lakes and found equilibrium phases in only 17 lakes.

In this study, we analyzed phytoplankton functional groups, as well as phytoplankton composition, density, biomass, chlorophyll a (Chl a), and physical and chemical variables to assess the driving forces behind two shortterm succession phases in the Maixi River, based on the adaptations of functional groups to environmental changes. An advantage of a short-term study is that the space-and-time substitution problem is avoided (Cardoso and Marques, 2003). Our primary objectives were to understand phytoplankton response mechanisms to environmental changes, by evaluating the phytoplankton functional groups in two succession phases and if there is a steady-state period of phytoplankton in this succession process. We expected variability in phytoplankton succession to be driven by the environment factors, which were steady-state phenomena during the short-term duration of the study and, therefore, functional groups would allow assessing the ecological status of the Maixi River.

\section{METHODS}

\section{Study site}

Maixi River is one of the four main tributaries of the Baihua Reservoir (BHR), flowing into its wharf area. It is a shallow (6-8 $\mathrm{m}$ depth), and the water quality is affected by the surrounding sewage from residents, agriculture, and industry. The BHR is located within the catchment of the Maotiao River, which is a branch of the Wujiang tributary of the Yangtze River in China, and acts as a second cascade of the hydropower station on the Maotiao River and provides drinking water for Guiyang City (Li et al., 2013). As the linkage between rivers and lakes, Maixi River ecological environment has a direct impact in phytoplankton composition structure and water quality in BHR. Previous studies showed that frequent activities, large amount of pollutants, and complex hydrological conditions affected phytoplankton composition structure of the Maixi River (Li et al. 2011, 2013).

The sampling site $\left(26^{\circ} 65^{\prime} 78.02^{\prime \prime} \mathrm{N}, 106^{\circ} 54^{\prime} 28.06^{\prime \prime}\right.$ E) was at the mouth of the Maixi River (Fig. 1). Sampling was conducted from August to September 2013 (summer, phase I) and from March to May 2014 (late spring and early summer, phase II). Daily water samples were taken at the surface $(0.5 \mathrm{~m}$ layer $)$ and weekly water samples were taken at depth (from the $0.5 \mathrm{~m}$ to the bottom, at $1 \mathrm{~m}$ intervals). Phase I and phase II sampling of surface water samples lasted 43 and 63 days, respectively. Stratified water samples were divided into seven layers $(0.5-6 \mathrm{~m})$ in phase I and into nine layers $(0.5-8 \mathrm{~m})$ in phase II; each phase was sampled eight times. This sampling strategy had two purposes: understanding the succession of phytoplankton from spring to summer and verifying the existence of a steady-state in the process of succession. Thus, a short-term continuous

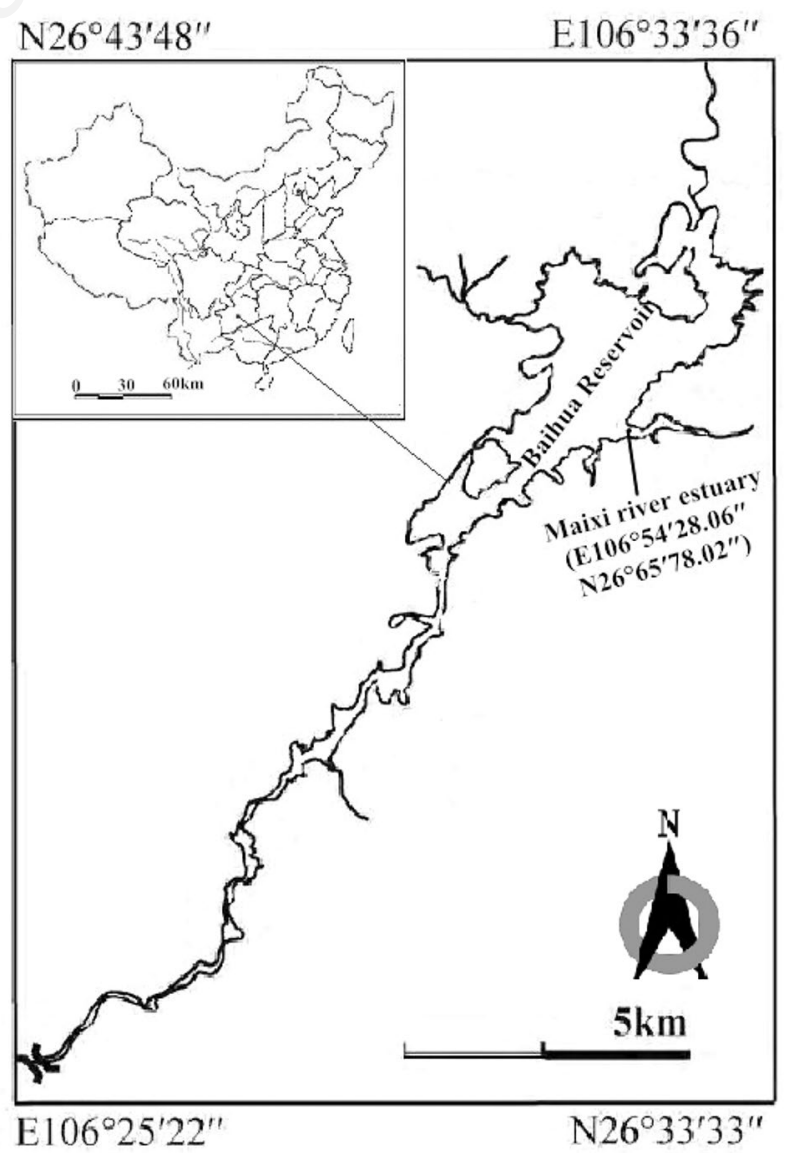

Fig. 1. Location of Baihua Reservoir and of the sampling site within Maixi River. 
monitoring of phytoplankton was needed to monitor rate changes in phytoplankton communities.

\section{Sample collection, processing, and evaluation}

The 105 surface samples and the 128 vertically stratified samples collected in the two phases were fixed with formalin (3-5\%) in the field. Firstly, each sample was concentrated by sedimentation $(50 \mathrm{~mL})$ after sedimentation for $48 \mathrm{~h}$ in the laboratory, registering the volume before and after concentrate. After complete mixing, $0.1 \mathrm{~mL}$ of concentrated sample was counted in a $0.1 \mathrm{~mL}$ counting chamber under microscope to quantify phytoplankton. The phytoplankton were counted on a cell-by-cell basis. Taxa were identified, and the number of individuals of each taxon was counted under a direct microscope (Olympus BX41). Phytoplankton biomass was estimated using phytoplankton density and specific volumes, assuming a phytoplankton-specific density of $1 \mathrm{mg} \mathrm{L}^{-1}$ (Sunjun et al., 1999). Phytoplankton functional groups were used as described by Reynolds et al. (2002) and Padisák et al. (2009).

\section{Physical and chemical parameters}

Water temperature (WT), dissolved oxygen (DO), and $\mathrm{pH}$ were measured using an YSI meter (6600V2) on site. Transparent depth (SD) was measured using a Secchi disk. Physical and chemical characteristics of water, including total nitrogen (TN), ammonium $\left(\mathrm{NH}_{4}-\mathrm{N}\right)$, nitrite $\left(\mathrm{NO}_{2}{ }^{-} \mathrm{N}\right)$, nitrate $\left(\mathrm{NO}_{3}-\mathrm{N}\right)$, total phosphorus (TP), dissolved inorganic phosphorus $\left(\mathrm{PO}_{4}-\mathrm{P}\right)$ and chlorophyll a (Chl.a), were determined using Chinese standard methods for water quality analysis GB3838-2002.

\section{Phytoplankton data and statistical analyses}

The rate of succession of the community composition $(\sigma)$ was calculated according to the methods of Cardoso and Marques (2003) and Pannard et al. (2008):

$$
\sigma_{\mathrm{s}}=\frac{\sum_{i=1}^{n}\left\{\left[\frac{b_{i}\left(t_{1}\right)}{B\left(t_{1}\right)}\right]\right\}-\left\{\left[\frac{b_{i}\left(t_{2}\right)}{B\left(t_{2}\right)}\right]\right\}}{\left(t_{1}-t_{2}\right)}
$$

where $b_{i}(t)$ is the density of the $n$ species; $B(t)$ is the sum of individuals constituting the community sampled; and $t_{1}$ and $t_{2}$ are phase I and phase II, respectively. The rate value $(\sigma)$ is low when the composition of the community does not fluctuate much and high values of $\sigma$ generally represent abrupt changes (Cardoso and Marques, 2003).

The relationship between the vertical distribution of phytoplankton and environmental factors was drawn on an isoline map using Surfer 8.0. The relationships among environmental variables and phytoplankton functional groups were evaluated using Pearson's correlation in SPSS 19.0. Ordination analysis was performed in
CANOCO 4.5. A detrended correspondence analysis (DCA) was first run to test whether the explored gradient fitted a linear or unimodal model, which allowed deciding on using a redundancy analysis (RDA). This RDA, which is a direct gradient analysis technique, was conducted to analyze the relationship between environmental factors and phytoplankton functional groups in the Maixi River, to determine the main environmental factors affecting phytoplankton functional groups succession. Linear response models were used for the ordination analyses conducted within short-term gradients. More than $1 \%$ of total biomass was used for the statistical analysis of data. For the RDA, environmental variables (except $\mathrm{pH}$ ) and biological data were $\log (\mathrm{x}+1)$-transformed to reduce skewness. The statistical significance of environmental variables explaining the variance in phytoplankton species obtained in the RDA was tested using a Monte Carlo permutation test and considering a P-level of 0.05 .

\section{RESULTS}

\section{Changes in phytoplankton composition and community}

Among the 101 species identified in the two phases, Chlorophyta were the most numerous, accounting for $56.43 \%$ of the total species count, followed by Bacillariophyta (20.79\%) and Cyanobacteria (14.85\%). Pyrrophyta, Cryptophyta, Chrysophyta, and Euglenophyta species were less abundant, accounting for approximately $8 \%$.

Average biomass and density of vertical and surface were higher in phase I than in phase II (Fig. 2). In phase I, vertical biomass ranged from 4.88 to $30.59 \mathrm{mg} \mathrm{L}^{-1}$ (mean $16.09 \mathrm{mg} \cdot \mathrm{L}^{-1}$ ), reaching the minimum at $6 \mathrm{~m}$ during the $3^{\text {rd }}$ week and the maximum at $3 \mathrm{~m}$ during the $7^{\text {th }}$ week. In phase II, vertical biomass ranged from 2.22 to $21.59 \mathrm{mg} \mathrm{L}{ }^{-1}$ (mean $8.60 \mathrm{mg} \cdot \mathrm{L}^{-1}$ ), reaching its minimum value at $8 \mathrm{~m}$ during the $4^{\text {th }}$ week; the phytoplankton biomass was lower during the first three weeks and achieved its maximum value at $2 \mathrm{~m}$ during the $8^{\text {th }}$ week.

Surface biomass ranged from 8.18 to $29.05 \mathrm{mg} \mathrm{L}^{-1}$ (mean $15.40 \mathrm{mg} \mathrm{L}^{-1}$ ) in phase $\mathrm{I}$, registering the minimum value at the $7^{\text {th }}$ day and increasing from the $28^{\text {th }}$ to the $35^{\text {th }}$ day, when it reached its maximum value, and then decreased. In phase II, surface biomass ranged between 2.46 and $50.61 \mathrm{mg} \mathrm{L}^{-1}$ (mean $17.03 \mathrm{mg} \mathrm{L}^{-1}$ ), reaching the highest value in the $67^{\text {th }}$ day (May 27) and the lowest in the $50^{\text {th }}$ day (March 27). From the $1^{\text {st }}$ to the $51^{\text {st }}$ day, biomass fluctuated slightly around $10 \mathrm{mg} \mathrm{L}^{-1}$, but after the $52^{\text {nd }}$ day (May 12) it increased gradually (Fig. 3).

Phytoplankton density ranged from $41.19 \times 10^{6}$ to $184.40 \times 10^{6}$ cells $\mathrm{L}^{-1}$ during phase I; densities were similar before the $28^{\text {th }}$ day, presented a slight increase from the $29^{\text {th }}$ to the $39^{\text {th }}$ day. In phase II, phytoplankton density 
ranged from $8.26 \times 10^{6}$ to $473.09 \times 10^{6}$ cells $\mathrm{L}^{-1}$ density increased slowly until the $25^{\text {th }}$ day, and rapidly from the $50^{\text {th }}$ to $67^{\text {th }}$ day (Fig. 3 ).

Phytoplankton biomass was positively correlated with DO $(r=0.289, P<0.05, n=55)$ and negatively correlated with TN $(\mathrm{r}=-0.315, \mathrm{P}<0.05, \mathrm{n}=55)$ and $\mathrm{TP}(\mathrm{r}=-0.307$, $\mathrm{P}<0.05, \mathrm{n}=55$ ) in phase I. In phase II, the biomass of phytoplankton was positively correlated with WT $(r=0.480$, $\mathrm{P}<0.01, \mathrm{n}=72)$ and negatively correlated with $\mathrm{TN}(\mathrm{r}=$ $-0.367, \mathrm{P}<0.01, \mathrm{n}=72), \mathrm{NO}_{3}-\mathrm{N}(\mathrm{r}=-0.478, \mathrm{P}<0.01, \mathrm{n}=72)$, and $\mathrm{NH}_{4}-\mathrm{N}(\mathrm{r}=-0.420, \mathrm{P}<0.01, \mathrm{n}=72)$.

\section{Short-term succession characteristics}

Phytoplankton taxa were sorted into 22 functional groups in phase I and 21 functional groups in phase II (Tab. 1). We found similar changes in the relative biomass of vertical and surface phytoplankton functional groups determined weekly and daily, respectively (Figs. 2 and 3).

In phase I, functional groups S1 (Pseudanabaena limnetica), D (Synedra sp.), Y (Cryptomonas sp.), P (Staurastrum sp.), and Lo (Peridinium sp.) considerably contributed to total biomass. Dominant phytoplankton species of sur-

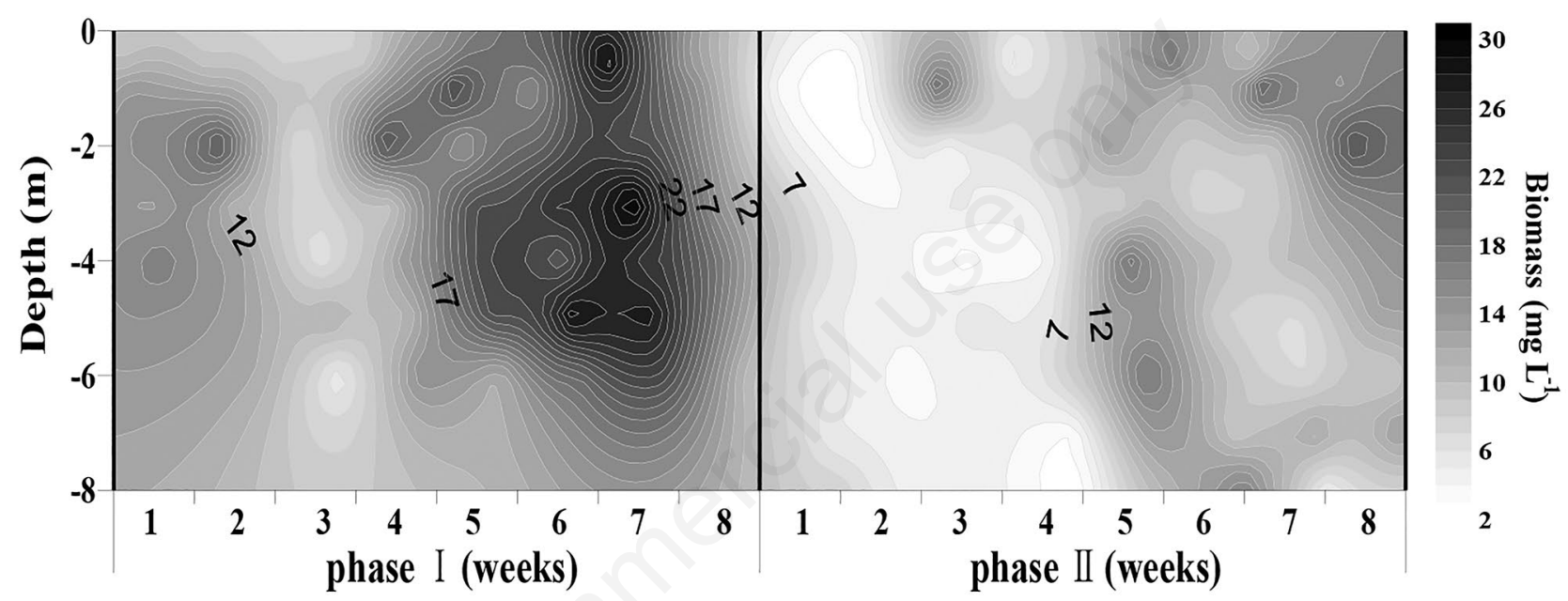

Fig. 2. Vertical distribution of phytoplankton biomass x-axis: vertical sampling once a week, eight times during each study phase. Phase I, summer, from August to September 2013; phase II, late spring and early summer, from March to May 2014.

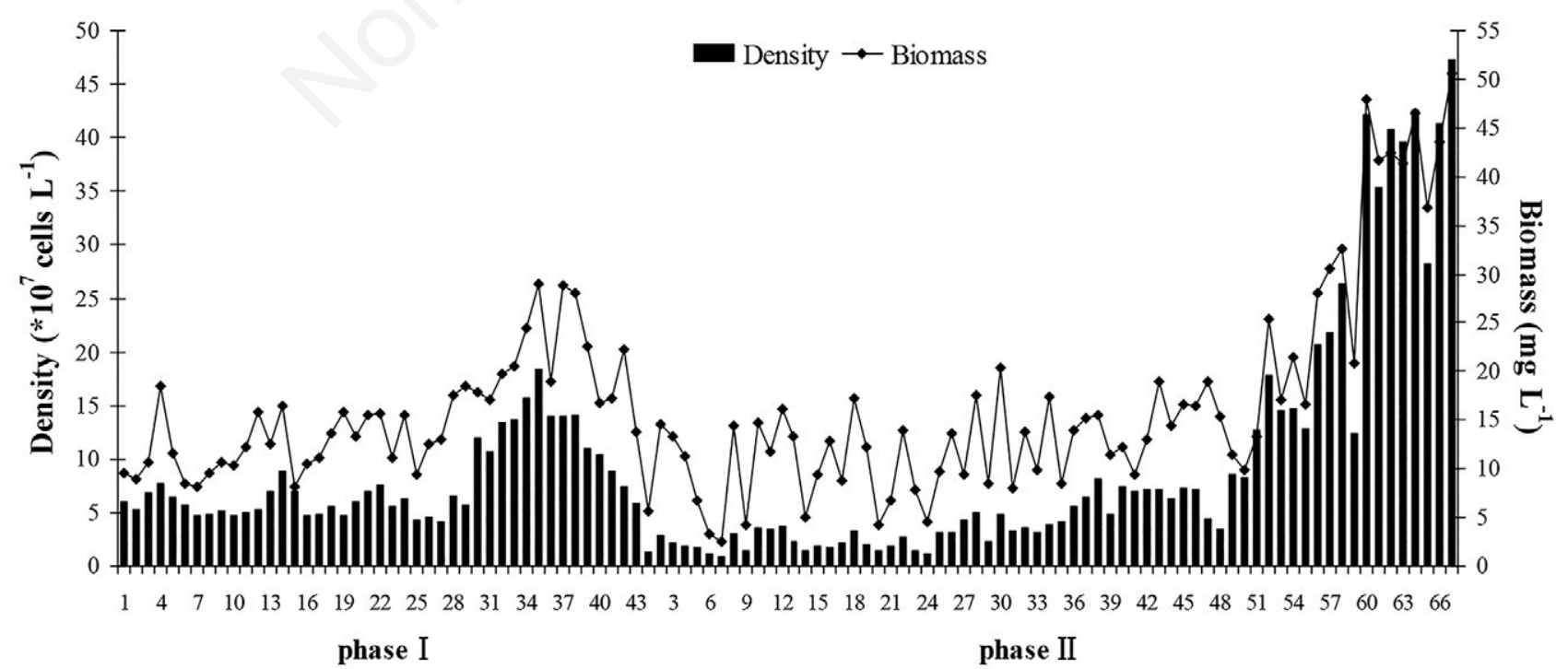

Fig. 3. Changes in surface phytoplankton biomass and density during each sampling period x-axis: phase I and phase II sampling of surface water samples lasted 42 and 63 days. 
face phytoplankton in phase I accounted for $70.85 \%$ of the total biomass. Among this, S1 biomass ranged from 17.39 to $61.23 \%$ of the total biomass, followed by Lo (19\%), P $(17 \%)$, Y $(10 \%)$, and D (15\% before the $29^{\text {th }}$ day and then gradually reduced to around 5\%) (Fig. 4a). Early in phase I ( $1-32^{\text {th }}$ day), relative biomass of S1 was low $(<10 \%)$, but it gradually increased to $25 \%$ from the $33^{\text {th }}$ to the $48^{\text {th }}$ day, and then peaked to about $60 \%$ (Fig. 4a).

In phase II, the total biomass of the dominant phytoplankton functional groups S1 (P. limnetica), D (Synedra sp.), Y (Cryptomonas sp.), F (Oocystis sp.), and X2 (Chlamydomonas sp.) at the surface ranged from 29.95 to $89.74 \%$ (average $69.82 \%$ ). The $\mathrm{Y}$ and $\mathrm{S} 1$ functional groups alternately accounted for $10 \%$ to $33 \%$ of the total biomass, and groups $\mathrm{F}$ and X2 were dominant from March 17 to March 24 with an average relative biomass as high as 30\%; $\mathrm{Y}$ accounted for $32 \%$ of the total biomass, but this was gradually reduced from the $25^{\text {th }}$ to $57^{\text {th }}$ day. Early in phase II (1-32 $2^{\text {nd }}$ day), relative biomass of S1 was low $(<10 \%)$ but it increased gradually to about $25 \%$ from the $33^{\text {rd }}$ to the $48^{\text {th }}$ day, and then peaked to about $60 \%$ (Fig. $4 \mathrm{~b}$ ).

\section{Short-term succession rate $(\sigma)$}

Rates of change in the phytoplankton community were broader in phase II than in phase I. In summer (phase I) rates ranged from 0 to 0.144 day $^{-1}$, attaining the highest value from $14^{\text {th }}$ to $15^{\text {th }}$ day (Fig. 5a). Rates of change were higher from $11^{\text {th }}$ to $30^{\text {th }}$ day, and relatively stable from the $1^{\text {st }}$ to $10^{\text {th }}$ day and from $31^{\text {st }}$ to $41^{\text {st }}$ day (Fig. $5 \mathrm{a}$ ). In phase II, rates of change were between 0.009 and 0.370 day $^{-1}$ (Fig. $5 \mathrm{~b}$ ), being higher from the $1^{\text {st }}$ to $53^{\text {rd }}$ day and relatively stable from the $54^{\text {th }}$ to $67^{\text {th }}$ day (Fig. 5b). In phase I, the rate of change was the largest from the $8^{\text {th }}$ to $15^{\text {th }}$ day (Fig. 5a). In phase II, the rate of change was variable (Fig. 5b), and changes in density and relative biomass were also large (Fig. 3; Fig. 4). The relative density of S1, for example, averaged $31.87 \%$ from the $1^{\text {st }}$ to $30^{\text {th }}$ day (Fig. $5 b$ ).

\section{Main environmental factors driving at the short-term succession}

Average water temperature was higher in phase I than in phase II and there was no thermal stratification of water

Tab. 1. Phytoplankton functional groups and their typical habitat were used as described by Reynolds et al. (2002) and Padisák et al. (2009).

\begin{tabular}{|c|c|c|c|c|}
\hline $\begin{array}{l}\text { Functional } \\
\text { groups }\end{array}$ & Most important taxa & Typical habitat & $\begin{array}{c}\text { Phase } \\
\text { I }\end{array}$ & $\begin{array}{c}\text { Phase } \\
\text { II }\end{array}$ \\
\hline $\mathrm{B}$ & Cyclotella sp. & Vertically mixed, mesothrophic small medium lakes & + & + \\
\hline $\mathrm{C}$ & $\begin{array}{l}\text { Asterionella formosa } \\
\text { Melosira ambigua }\end{array}$ & Mixed, eutrophic small medium lakes & + & + \\
\hline $\mathrm{D}$ & Synedra acus & Shallow, enriched turbid waters, including rivers & + & + \\
\hline $\mathrm{E}$ & Dinobryon divergens & Usually small, oligotrophic, base poor lakes or heterothrophic ponds & + & + \\
\hline $\mathrm{F}$ & Oocystis sp., Kirchnecriella sp. & Clear epilimnia & + & + \\
\hline G & Eudorina elegans & Short, nutrient-rich water columns & + & + \\
\hline $\mathrm{H} 1$ & Aphanizomenon sp. & Dinitrogen-fixing, nostocaleans & + & + \\
\hline $\mathrm{J}$ & Scenedesmus sp., Pediastrum sp., Coelastrum sp. & Shallow, enriched lakes ponds and rivers & + & + \\
\hline $\mathrm{L}_{\mathrm{M}}$ & Navicula sp., Achnanthes sp. & Summer epilimnia in eutrophic lakes & + & + \\
\hline $\mathrm{LO}$ & Dactyloccopsis, Peridinium & Summer epilimnia in mesotrophic lakes & + & + \\
\hline $\mathrm{M}$ & Microcystis sp. & Daily mixed layers of small eutrophic, low latitude lakes & + & + \\
\hline MP & Chlorella vulgaris & Frequently stirred up, inorganically turbid shallow lakes & + & + \\
\hline $\mathrm{P}$ & $\begin{array}{l}\text { Staurastrum sp. } \\
\text { Fragilaria } \text { sp. }\end{array}$ & Eutrophic epilimnia & + & + \\
\hline $\mathrm{S} 1$ & Pseudanabaena limnetica & Turbid mixed layers & + & + \\
\hline $\mathrm{S}_{\mathrm{N}}$ & Raphidiopsis, Cylindrospermopsis sp. & Warm mixed layers & + & + \\
\hline $\mathrm{T}$ & Quadrigula sp. & Deep, well-mixed epilimnia & + & + \\
\hline $\mathrm{T}_{\mathrm{C}}$ & Phormidium sp. & $\begin{array}{l}\text { Eutrophic standing waters, or slow- flowing rivers with emergent } \\
\text { macrophytes }\end{array}$ & + & \\
\hline W1 & Euglenophyta sp. & Small organic ponds & + & + \\
\hline W2 & Trachelomononas sp. & Shallow mesotrophic lakes & + & + \\
\hline $\mathrm{X} 1$ & Pyrrophyta, Chroococcus sp. & Shallow mixed layers in enriched conditions & + & + \\
\hline $\mathrm{X} 2$ & Chlamydomonas sp. & Shallow, clear mixed layers in meso-eutrophic lakes & + & + \\
\hline $\mathrm{Y}$ & Cryptophyta & Usually, small, enriched lakes & + & + \\
\hline
\end{tabular}

Phase I, August 16 - September 26, 2013; Phase II, March 21 - May 22, 2014. 
column in any of the two seasons. In phase I (Fig. 6a), water temperature was usually above $21^{\circ} \mathrm{C}$, despite a reduction in $5^{\text {th }}$ and $8^{\text {th }}$ week. In phase II, the temperature ranged between 9.2 and $21.3^{\circ} \mathrm{C}$, with an average of $16.5^{\circ} \mathrm{C}$ (Tab. 2), gradually increasing from the $1^{\text {st }}$ to $5^{\text {th }}$ weeks, and slowly decreasing from the surface to the bottom after the second week; water temperature was always lower at the bottom (6-8 m) than at other depths (Fig. 6a).

In phase I, DO concentrations were lower than in phase II, ranging from 2.14 to $7.75 \mathrm{mg} \mathrm{L}^{-1}$, with an average of $5.17 \mathrm{mg} \mathrm{L}^{-1}$ (Tab. 2). The distributions of DO were similar to that of water temperature, with no obvious vertical stratification in the first two weeks (Fig. 6b). The lowest concentration of DO was registered at the $3^{\text {rd }}$ week, and the highest on the $3^{\text {rd }}$ and $4^{\text {th }}$ weeks. In phase II, DO ranged from 3.91 to $10.01 \mathrm{mg} \mathrm{L}^{-1}$, with an average of 7.31 $\mathrm{mg} \mathrm{L}^{-1}$ (Tab. 2). In phase I, $\mathrm{pH}$ varied from 7.39 to 8.64 , with an average of 8.16; in phase II, it ranged from 7.29 to 8.5 , with a mean value of 8.08 . There was a gradual decrease of $\mathrm{pH}$ with depth in both phases (Fig. 6c).

No stratification was found for TP and TN (Fig. 6 d,e). The TP concentrations ranged from 10 to $120 \mu \mathrm{g} \mathrm{L}^{-1}$, with an average of $16 \mu \mathrm{g} \mathrm{L}^{-1}$ in phase I and $39 \mu \mathrm{g} \mathrm{L}^{-1}$ in phase II (Tab. 2). The lowest TP concentration occurred on the $3^{\text {rd }}$ week of phase I (Fig. 6d). Because $\mathrm{PO}_{4}-\mathrm{P}$ concentration was extremely low, it was not a main component of TP. TN was

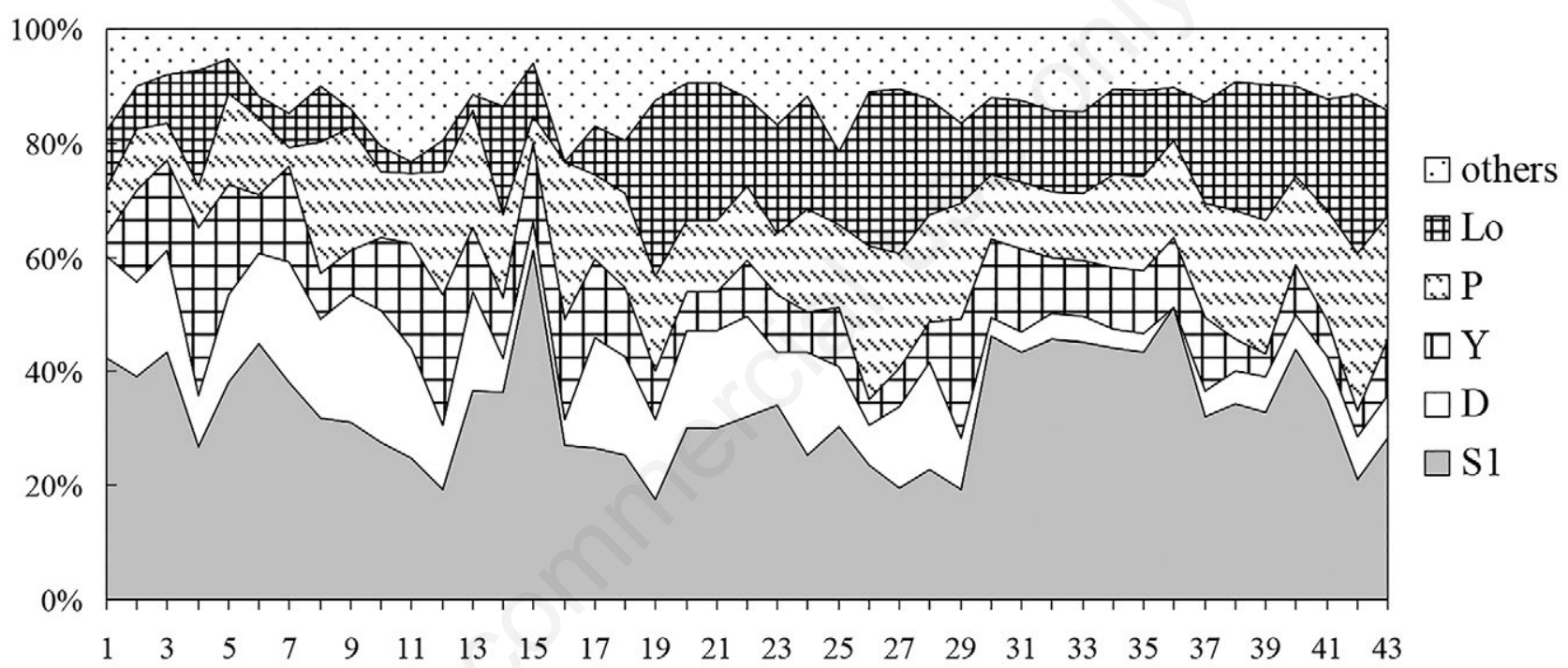

(a) Phase I

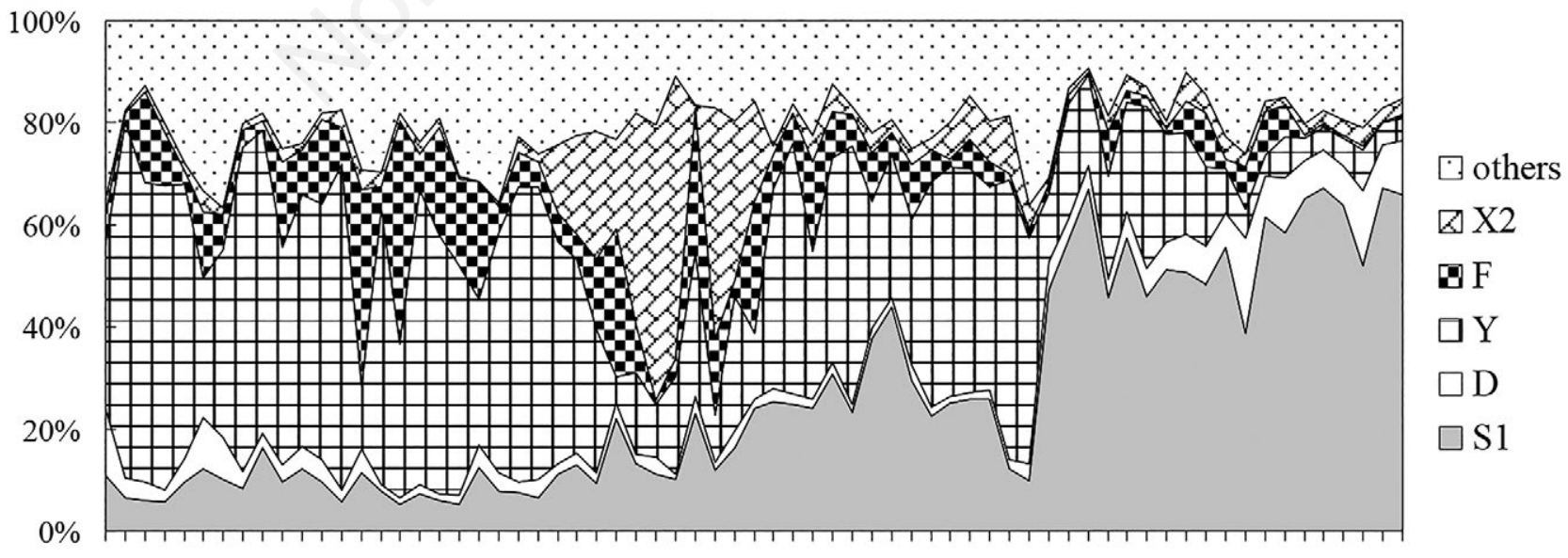

(b) Phase II

Fig. 4. Relative biomass (\%) of surface functional groups. a) Others: $X 2, L_{M}, F, B, C, E, G, H 1, J, M, M P, S 2, S_{N}, T, T_{C}$, W1, W2, X1. b) Others: B, P, Lo, C, E, G, H1, J, L 
Tab. 2. Environmental variables in the Maixi River during the two periods.

\begin{tabular}{|c|c|c|c|c|c|}
\hline & & & & & \\
\hline & Unit & Mean & Range & Mean & Range \\
\hline Water temperature & ${ }^{\circ} \mathrm{C}$ & 23.65 & $21.1 \sim 25.9$ & 16.5 & $9.2 \sim 21.3$ \\
\hline $\mathrm{DO}$ & $\mathrm{mg} \mathrm{L}^{-1}$ & 5.17 & $4.09 \sim 7.75$ & 7.31 & $3.91 \sim 10.01$ \\
\hline Conductivity & $\mu \mathrm{s} \mathrm{m}^{-1}$ & 470.11 & $420 \sim 545$ & 532.04 & $498 \sim 689$ \\
\hline $\mathrm{pH}$ & & 8.16 & $7.39 \sim 8.64$ & 8.08 & $7.29 \sim 8.5$ \\
\hline $\mathrm{TP}$ & $\mu \mathrm{g} \mathrm{L}^{-1}$ & 16 & $10 \sim 40$ & 39 & $10 \sim 120$ \\
\hline $\mathrm{TN}$ & $\mathrm{mg} \mathrm{L}^{-1}$ & 1.83 & $1.55 \sim 2.48$ & 2.43 & $1.14 \sim 5.87$ \\
\hline $\mathrm{TN} / \mathrm{TP}$ & & 126.4 & $50.9 \sim 200.3$ & 72.7 & $17.0 \sim 233.1$ \\
\hline $\mathrm{NO}_{3}-\mathrm{N}$ & $\mathrm{mg} \mathrm{L}^{-1}$ & 1.28 & $1.007 \sim 2.17$ & 1.86 & $0 \sim 4.81$ \\
\hline $\mathrm{NO}_{2}-\mathrm{N}$ & $\mathrm{mg} \mathrm{L}^{-1}$ & 0.05 & $0.031 \sim 0.08$ & 0.035 & $0.022 \sim 0.056$ \\
\hline $\mathrm{NH}_{3}-\mathrm{N}$ & $\mathrm{mg} \mathrm{L}^{-1}$ & 0.011 & $0 \sim 0.05$ & 0.057 & $0 \sim 0.37$ \\
\hline $\mathrm{PO}_{4}-\mathrm{P}$ & $\mu \mathrm{g} \mathrm{L}^{-1}$ & 2 & $0 \sim 4$ & 3 & $0 \sim 7$ \\
\hline Chlorophyll a & $\mu \mathrm{g} \mathrm{L}^{-1}$ & 24.7 & $16.09 \sim 32.3$ & 17.1 & $0.37 \sim 33.45$ \\
\hline SD & $\mathrm{m}$ & 1.1 & $0.8 \sim 1.4$ & 1.36 & $0.9 \sim 1.75$ \\
\hline
\end{tabular}

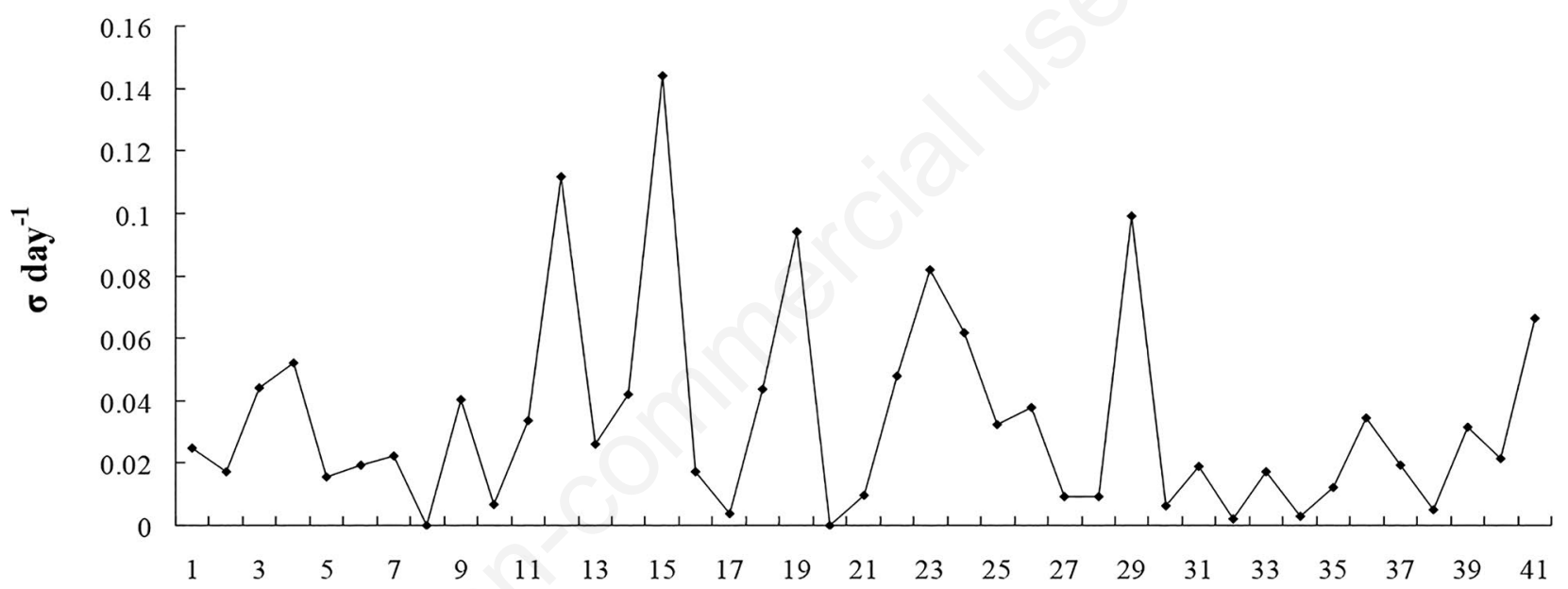

Phase I

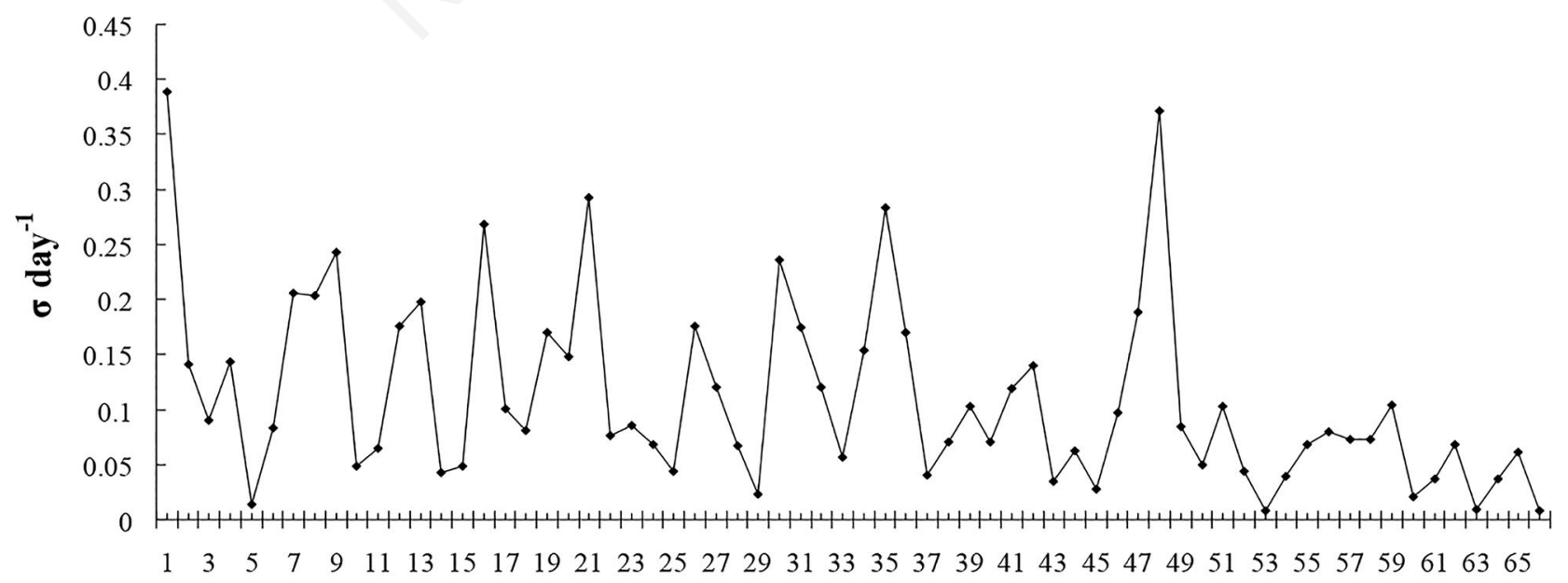

Phase II

Fig. 5. Rate of change in the phytoplankton community $\left(\sigma\right.$ day $\left.^{-1}\right)$ during the two sampling phases in the Maixi River. 

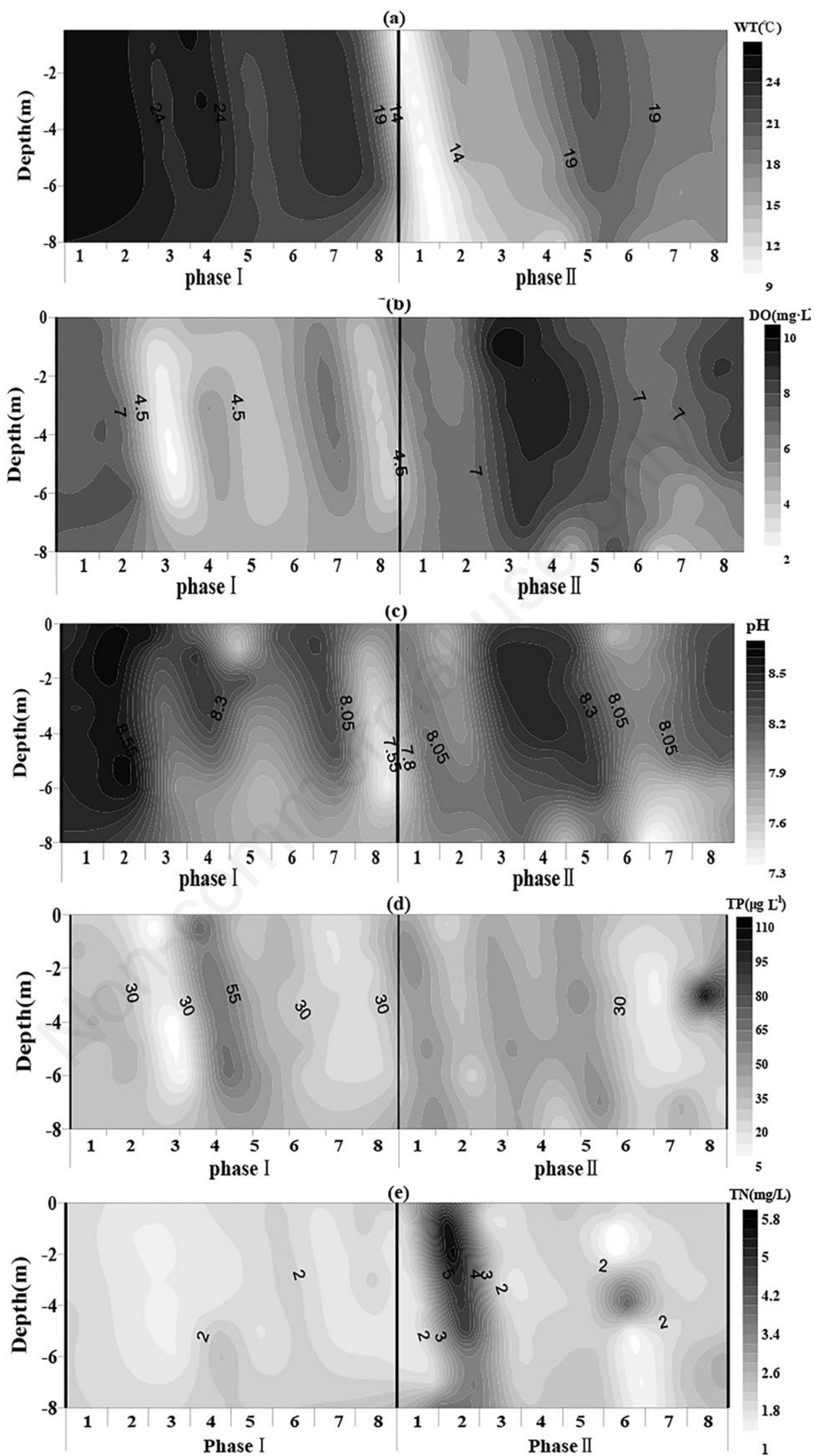

Fig. 6. Spatiotemporal distribution of the values of the main environmental variables. a) Water temperature $\left({ }^{\circ} \mathrm{C}\right)$; b) dissolved oxygen $\left.\left.\left(\mathrm{mg} \mathrm{L}^{-1}\right) ; \mathrm{c}\right) \mathrm{pH} ; \mathrm{d}\right)$ total phosphorus $\left.\left(\mathrm{mg} \mathrm{L}^{-1}\right) ; \mathrm{e}\right)$ total nitrogen $\left(\mathrm{mg} \mathrm{L}^{-1}\right)$. 
between one and two orders of magnitude higher than TP (Tab. 2). Nitrate $\left(\mathrm{NO}_{3}-\mathrm{N}\right)$ was the main component of TN, its strongest correlations with TN obtained by Pearson's correlation analysis were $\mathrm{r}=0.741(\mathrm{P}<0.01, \mathrm{n}=55)$ and $\mathrm{r}=$ $0.891(\mathrm{P}<0.01, \mathrm{n}=55)$. The SD was generally low, with an average of $1.1 \mathrm{~m}$ in phase I and an average of $1.36 \mathrm{~m}$ in phase II (Tab. 2).

\section{RDA of phytoplankton functional groups and environmental factors}

The results of the DCA ordination with phytoplankton functional groups accounted for gradient lengths of 1.267 and 1.542 in phase I and II, respectively. Thus, linear ordination methods such as RDA should be used. In the diagram, the cosine of the angle of environmental factors and species variables represents the correlation between them; an acute angle is a positive correlation and an obtuse angle is a negative correlation. There were 9 environmental factors in both phases, (TP, TN, $\mathrm{NO}_{3}-\mathrm{N}$, $\mathrm{NO}_{2}-\mathrm{N}, \mathrm{NH}_{4}-\mathrm{N}, \mathrm{WT}, \mathrm{DO}, \mathrm{pH}$ and $\mathrm{SD}$ ), and 12 functional groups in phase I and 16 functional groups in phase II. In phase I, the Monte Carlo test $(\mathrm{P}<0.05)$ demonstrated that the ordination along axis 1 was statistically significant with an eigenvalue of $0.284 ; 75.8 \%$ of the cumulative variance in species distribution was explained by the first two axes (Tab. 3). The most effective explanatory factors were SD $(\mathrm{P}<0.01, \mathrm{~F}=8.51, \mathrm{n}=499)$ and $\mathrm{TN}(\mathrm{P}<0.01$, $\mathrm{F}=5.224, \mathrm{n}=499$ ), both playing a significant role in the short-term succession. Correlations also showed that WT was the most important variable $(\mathrm{P}<0.01, \mathrm{~F}=5.134$, $\mathrm{n}=499$ ). Regarding phytoplankton functional groups, $\mathrm{S} 1$ was located towards higher DO and SD values, whereas $\mathrm{X} 2, \mathrm{P}, \mathrm{T}$ and $\mathrm{L}_{\mathrm{O}}$ towards higher SD. Most phytoplankton functional groups (T, Lo, P, X2, $\mathrm{L}_{\mathrm{M}}, \mathrm{Y}, \mathrm{F}$ and J) were closely related to four environmental factors, appearing at the bottom left of the diagram. In addition, D and S2 were placed towards higher values of $\mathrm{NO}_{2}-\mathrm{N}, \mathrm{G}$ and $\mathrm{B}$ were towards higher $\mathrm{NH}_{4}-\mathrm{N}$ concentrations, MP was placed towards of water temperature (Fig. 7a).
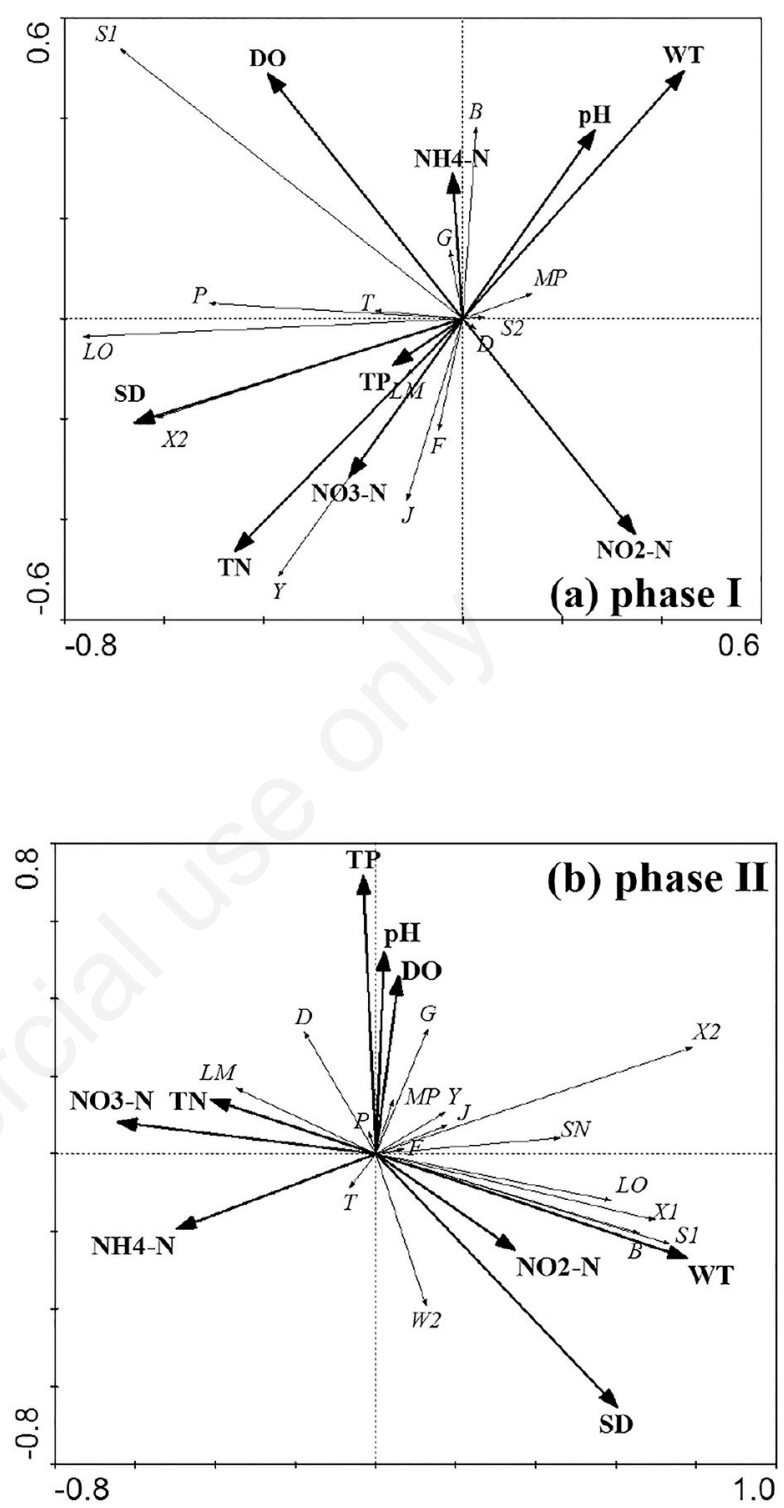

Fig. 7. Redundancy analysis of phytoplankton functional groups related to environmental factors in the Maixi River.

Tab. 3. Main results of redundancy analysis and Monte Carlo permutation test for the relationship between biovolume of phytoplankton species and environment variables.

\begin{tabular}{|c|c|c|c|c|c|c|c|c|c|c|}
\hline \multirow[b]{2}{*}{ Axes } & \multicolumn{4}{|c|}{ Phase I } & \multicolumn{6}{|c|}{ Phase II } \\
\hline & $\lambda_{1}$ & $\lambda_{2}$ & $\lambda_{3}$ & $\lambda_{4}$ & $\begin{array}{c}\text { Total } \\
\text { variance }\end{array}$ & $\lambda_{1}$ & $\lambda_{2}$ & $\lambda_{3}$ & $\lambda_{4}$ & $\begin{array}{c}\text { Total } \\
\text { variance }\end{array}$ \\
\hline Eigenvalues & 0.284 & 0.087 & 0.038 & 0.022 & 1 & 0.325 & 0.040 & 0.028 & 0.022 & 1 \\
\hline Species-environment correlations & 0.793 & 0.758 & 0.580 & 0.741 & & 0.881 & 0.611 & 0.492 & 0.467 & \\
\hline $\begin{array}{l}\text { Cumulative percentage variance } \\
\text { of species data } \\
\text { of species-environment relation }\end{array}$ & $\begin{array}{l}28.4 \\
62.7\end{array}$ & $\begin{array}{l}37.1 \\
81.9\end{array}$ & $\begin{array}{l}40.9 \\
90.2\end{array}$ & $\begin{array}{l}43.1 \\
95.0\end{array}$ & & $\begin{array}{l}32.5 \\
74.0\end{array}$ & $\begin{array}{l}36.6 \\
83.1\end{array}$ & $\begin{array}{l}39.3 \\
89.4\end{array}$ & $\begin{array}{l}41.5 \\
94.3\end{array}$ & \\
\hline Sum of all eigenvalues & & & & & 1 & & & & & 1 \\
\hline Sum of all canonical eigenvalues & & & & & 0.453 & & & & & 0.440 \\
\hline
\end{tabular}


In phase II, the Monte Carlo test $(\mathrm{P}<0.05)$ demonstrated that axis 1 was statistically significant $(\mathrm{P}<0.01)$ with an eigenvalue of $0.325 ; 61.1 \%$ of the cumulative variance in species distribution was explained by the first two axes (Tab. 3). The most effective explanatory factors were WT $(\mathrm{P}<0.01, \mathrm{~F}=18.27, \mathrm{n}=499), \mathrm{NO}_{3}-\mathrm{N}(\mathrm{P}<0.01$, $\mathrm{F}=11.88, \mathrm{n}=499), \mathrm{SD}(\mathrm{P}<0.01, \mathrm{~F}=11.24, \mathrm{n}=499), \mathrm{NH}_{4}-\mathrm{N}$ $(\mathrm{P}<0.01, \mathrm{~F}=6.66, \mathrm{n}=499)$, and $\mathrm{TN}(\mathrm{P}<0.01, \mathrm{~F}=5.12$, $\mathrm{n}=499$ ), and played significant roles in the short-term succession of phytoplankton functional groups. While WT (0.684), $\mathrm{NO}_{3}-\mathrm{N}(-0.566)$ and $\mathrm{SD}(0.531)$ were highly correlated with axis 1 , TP (0.438), $\mathrm{pH}(0.317)$, and SD ($0.398)$ were highly correlated with axis 2 . Most phytoplankton functional groups (S1, B, X1, Lo, J, $\mathrm{S}_{\mathrm{N}}, \mathrm{F}$, $\mathrm{X} 2$, J and $\mathrm{Y}$ ) were located towards higher $\mathrm{WT}, \mathrm{NO}_{2}-\mathrm{N}$ and SD. In addition, G, MP, P and D were located towards higher $\mathrm{DO}, \mathrm{pH}$, and $\mathrm{TP}$, whereas $\mathrm{D}, \mathrm{L}_{\mathrm{M}}$, and $\mathrm{P}$ towards higher TN and TP concentrations (Fig. 7b).

\section{DISCUSSION}

The short-term succession of phytoplankton response mechanisms to environmental changes

Phytoplankton functional group composition in the Maixi River had particular spatial and temporal distribution characteristics. Our study site is connected to the river and lake ecosystems; thus, its hydrological environment is complex, which influences phytoplankton community dynamics. There was no thermal stratification of water during the study period, phytoplankton community changes were similar between layers, as was observed in shallow water by Nixdorf and Deneke (1997). The dominant functional groups in late spring and early summer were $\mathrm{Y}$ and $\mathrm{S} 1$, but in summer S1 absolutely dominated. Based on the phytoplankton steady-state conditions, we defined a steady-state in summer and two steady-state periods in late spring and early summer. The steady-state of dominant phytoplankton was controlled by many factors, including nutrients, light, and water stagnation, which changed frequently from deficiency to superfluity (Mischke and Nixdorf, 2003), and by coexistence mechanisms in the relative equilibrium state. There were competition and coexistence mechanism of phytoplankton; both S1 and Y tolerate highly light-deficient conditions, but the first one is sensitive to flushing, contrarily to D that is tolerant to it. In Maixi river S1 is well adapted to the less transparency conditions. Functional group S1 is usually characterized by cyanobacteria, are adapted to high temperature, forming groups, floating, and multiplying fast, which dominate during the summer period (Çelekli and Öztürk, 2014). Some studies have shown that populations of Cyanobacteria, which comprise a few species within the functional group of S1, regularly occur in summer in different water bodies around the world
(Rücker et al., 1997; Padisák et al., 2003; Gemelgo et al., 2009; Borics et al., 2012; Li et al., 2013; Stević et al., 2013; Hu et al., 2016). Both Lo and Y have a flagellum that allows their survival in multiple water layers when adverse conditions such as weather changes and water body disturbance are encountered (Padisák et al., 2009; Naselli-Flores and Barone, 2003).

Seasonal variation in phytoplankton is closely related to changes in the water environment, such as sudden changes in temperature, nutritional status, disturbance patterns, zooplankton grazing pressure, and hydrodynamics (Padisák et al., 2003; Wilk-Woźniak and Żurek, 2006; Marija et al., 2007). In fact, changes in water temperature was the main environmental factor affecting the growth of S1 during late spring and early summer (i.e., phase II). Many studies also pointed out that water temperature plays a major role in seasonal changes, growth, and community structure of phytoplankton (Padisák et al., 2003; Salmaso and Zignin, 2010). In summer, with continuously high temperature, this variable did not have a significant effect and DO was the main factor influencing the rate of succession.

Besides, ratios of TN/TP have also been used to examine nutrient limitations on phytoplankton growth (Becker et al., 2010). Given the high TN concentrations observed during the two study periods, our results suggest that TP was probably a limiting factor for phytoplankton growth; the $\mathrm{N}$ present in the Maixi River was mainly in the form of $\mathrm{NO}_{3}-\mathrm{N}$, which reflected the amount of exogenous pollutants in the water. In addition, this showed that the water self-purification process was ongoing, with the high ammonia utilization ratio leading to increasing nitrate contents. Therefore, these stable and suitable environmental conditions are able to the establishment of a steady state for a longer time, and a less marked rate of phytoplankton change. Our hypothesis was confirmed, the variability in phytoplankton succession to be driven by the physical and chemical factors, which were steady-state phenomena during the short-term duration of the study.

\section{Reaction of phytoplankton functional groups to ecological status}

Because the phytoplankton functional groups approach can be used without geographic limitations (Padisák et al., 2009; Crossetti and Bicudo, 2008b; Becker et al., 2009; Pasztaleniec and Poniewozik, 2010), and habitat requirements and phytoplankton are sensitive to changes in water quality (Çelekli and Öztürk, 2014), it is a potential monitoring tool for the assessment of ecological status in the context of the Water Framework Directive (Cellamare et al., 2012). For instance, phytoplankton functional groups estimated reliable water quality states between hypertrophic and oligotrophic conditions in a reservoir of Turkey (Çelik and Sevindik, 2015), indicated eutrophication due to human impacts 
along the river Loire in France (Abonyi et al., 2012), and allowed an ecological assessment of French Atlantic lakes (Cellamare et al., 2012).

This system is hypereutrophic based on chlorophyll, $\mathrm{SD}, \mathrm{TN}$ and sometimes due to TP, and also the presence of the dominant functional groups $\mathrm{S} 1, \mathrm{Lo}$, and $\mathrm{P}$ indicated this trophic condition. In addition, we found high values of biomass and density from spring to summer, which is the most likely period for the occurrence of phytoplankton blooms of P. limnetica (in May particularly). Many studies have confirmed that the worse the ecological condition of the water, the higher the thin filamentous cyanobacteria biomass (Hajnal and Padisák, 2008). The water management should take preventive measures against this phenomenon during this month in future. Baihua reservoir is one of the suppliers of drinking water for Guiyang City, and Maixi River has a direct impact on the water quality of this reservoir, threatening the safety of human life. On the other hand, the human activities in this area varied frequently, and a large amount of pollutants and complex hydrological conditions affected phytoplankton composition (Li et al., 2011, 2013). For that situation, we need to pay attention to control pollution in key river valleys and regions, and we should take appropriate measures to reduce nutrient input, especially during the period of the temperature rise and continuous rainfall.

\section{CONCLUSIONS}

- This study confirmed the potential utility of the phytoplankton functional groups approach in the Maixi River. Two consecutive short-term sampling phases yielded 23 functional groups; phase I was dominated by the functional group S1, and phase II was dominated by the functional groups $\mathrm{Y}$ and $\mathrm{S} 1$.

- Water temperature was a key factor in the selection of phytoplankton species and were likely to be the critical factors affecting phytoplankton communities in the steady-states occurring in later spring to early summer, whereas SD and DO were key factors during summer. Functional groups S1, D, and Y were in a steady-state dynamics in the Maixi River.

- Based on phytoplankton functional groups and the environmental factors Maixi River can be classified as hypertrophic. Functional group S1 may begin to grow in May, and this period may coincide with phytoplankton blooms. Therefore, water resources management should focus on this period.

\section{ACKNOWLEDGMENTS}

We thank two anonymous reviewers for helpful comments. This research was in part supported by the Natural
Science Foundation of China (U1612442), the department of science and technology of Guizhou Province ([2015]2001, [2015]10, [2014]7001), Water Resources Department of Guizhou Province KT201401 and the department of science and technology of Baiyun ([2014]69, [2014]70).

\section{REFERENCES}

Abonyi A, Leitão M, Lançon AM, Padisák J, 2012. Phytoplankton functional groups as indicators of human impacts along the River Loire (France). Hydrobiologia 698:233-249.

Anderson DM, Rengefors K, 2006. Community assembly and seasonal succession of marine dinoflagellates in a temperate estuary: The importance of life cycle events. Limnol. Oceanogr. 51:860-873.

Becker V, Huszar V, Crossetti L, 2009. Responses of phytoplankton functional groups to the mixing regime in a deep subtropical reservoir. Hydrobiologia 628:137-151.

Becker V, Caputo L, Ordóñes J, Marcé R, Armengol J, Crossetti LO, Huszar VLM, 2010. Driving factors of the phytoplankton functional groups in a deep Mediterranean reservoir. Water Res. 44:3345-3354.

Bonilla S, Conde D, Aubriot L, Pérez MD, 2005. Influence of hydrology on phytoplankton species composition and life strategies in a subtropical coastal lagoon periodically connected with the Atlantic Ocean. Estuar. Coast. 28:884-895.

Borics G, Tóthmérész B, Lukács BA, Várbíró G, 2012. Functional groups of phytoplankton shaping diversity of shallow lake ecosystems. Hydrobiologia 698:251-262.

Cardoso LDS, Marques DDM, 2003. Rate of change of the phytoplankton community in Itapeva Lake (North Coast of Rio Grande do Sul, Brazil), based on the wind driven hydrodynamic regime. Hydrobiologia 497:1-12.

Çelekli A, Öztürk B, 2014. Determination of ecological status and ecological preferences of phytoplankton using multivariate approach in a Mediterranean reservoir. Hydrobiologia 740:115-135.

Çelik K, Sevindik TO, 2015.The phytoplankton functional group concept provides a reliable basis for ecological status estimation in the Çaygören Reservoir (Turkey). Doga Turk. J. Bot. 39:1226-1230.

Cellamare M, Morin S, Coste M, Haury J, 2012. Ecological assessment of French Atlantic lakes based on phytoplankton, phytobenthos and macrophytes. Environ. Monit. Assess. 184:4685-4708.

Costa LS, Huszar VLM, Ovalle AR, 2009. Phytoplankton functional groups in a tropical estuary: hydrological control and nutrient limitation. Estuar. Coast. 32:508-521.

Crossetti LO, Bicudo CEM, 2005. Structural and functional phytoplankton responses to nutrient impoverishment in mesocosms placed in a shallow eutrophic Reservoir (Garças Pond), São Paulo, Brazil. Hydrobiologia 541:71-85.

Crossetti LO, Bicudo CEM, 2008a. Phytoplankton as a monitoring tool in a tropical urban shallow reservoir (Garças Pond): the assemblage index application. Hydrobiologia 610:161-173.

Crossetti LO, Bicudo CEM, 2008b. Adaptations in phytoplankton life strategies to imposed change in a shallow urban trop- 
ical eutrophic reservoir, Garças Reservoir, over 8 years. Hydrobiologia 614:91-105.

Dokulil MT, Teubner K, 2003. Steady state phytoplankton assemblages during thermal stratification in deep alpine lakes. Do they occur? Hydrobiologia 502:65-72.

Fonseca BM, Bicudo CEM, 2008. Phytoplankton seasonal variation in a shallow stratified eutrophic reservoir (Garças Pond, Brazil). Hydrobiologia 600:267-282.

Gemelgo MCP, Mucci JLN, Navaspereira D, 2009. Population dynamics: seasonal variation of phytoplankton functional groups in Brazilian reservoirs (Billings and Guarapiranga, São Paulo). Braz. J. Biol. 69:1001-1013.

Hajnal E, Padisák J, 2008. Analysis of long-term ecological status of Lake Balaton based on the ALMOBAL phytoplankton database. Hydrobiologia 599:227-237.

Howarth RW, 1998. An assessment of human influences on fluxes of nitrogen from the terrestrial landscape to the estuaries and continental shelves of the North Atlantic Ocean. Nutr. Cycl. Agroecosys. 52:213-223.

Hu R, Li Q, Han B, Naselli-Flores L, Padisak J, Salmaso N, 2016. Tracking management-related water quality alterations by phytoplankton assemblages in a tropical reservoir. Hydrobiologia 763:109-124.

Kruk C, Mazzeo N, Lacerot G, Reynolds CS, 2002. Classification schemes for phytoplankton: a local validation of a functional approach to the analysis of species temporal replacement. J. Plankton Res. 24:901-912.

Marija G, Plenković-Moraj A, Kralj K, Grigorszky I, PerošPucar D, 2007. The relationship between phytoplankton species dominance and environmental variables in a shallow lake (Lake Vrana, Croatia). Hydrobiologia 584:337-346.

Mieleitner J, Borsuk M, Bürgi HR, Reichert P, 2008. Identifying functional groups of phytoplankton using data from three lakes of different trophic state. Aquat. Sci. 70:30-46.

Mischke U, Nixdorf B, 2003. Equilibrium phase conditions in shallow German lakes: how Cyanoprokaryota species establish a steady state phase in late summer. Hydrobiologia 502:123-132.

Morabito G, Oggioni A, Panzani P, 2003. Phytoplankton assemblage at equilibrium in large and deep subalpine lakes: a case study from Lago Maggiore (N. Italy). Hydrobiologia 502: 37-48.

Naselli-Flores L, Padisák J, Dokulil MT, Chorus I, 2003. Equilibrium steady-state in phytoplankton ecology. Hydrobiologia 502:395-403.

Nixdorf B, Deneke R,1997. Why 'very shallow' lakes are more successful opposing reduced nutrient loads. Hydrobiologia 342/343:269-284.

Nixdorf B, Mischke U, Rücker J, 2003. Phytoplankton assemblages and steady state in deep and shallow eutrophic lakes: an approach to differentiate the habitat properties of Oscillatoriales. Hydrobiologia 502:111-121.

Li Q, Chen L, Xia P, Liu S, Chen F, Yu D, Li C, 2011. [Structure of phytoplankton community and its relationship with environmental factors at the estuary of Maixi River in Baihua
Reservoir, Guizhou Province].[Article in Chinese]. J. Lake Sci. 23:612-618.

Li Q, Chen L, Chen F, Gao T, Li X, Liu S, Li C, 2013. Maixi River estuary to the Baihua Reservoir in the Maotiao River catchment: phytoplankton community and environmental factors. Chin. J. Oceanol. Limn. 31:290-299.

Padisák J, Borics G, Fehér G, Grigorszky I et al., 2003. Dominant species, functional assemblages and frequency of equilibrium phases in late summer phytoplankton assemblages in Hungarian small shallow lakes. Hydrobiologia 502:157-168.

Padisák J, Crossetti L, Naselli-Flores L, 2009. Use and misuse in the application of the phytoplankton functional classification: A critical review with updates. Hydrobiologia 621:1-19.

Pasztaleniec A, Poniewozik M, 2010. Phytoplankton based assessment of the ecological status of four shallow lakes (Eastern Poland) according to Water Framework Directive-a comparison of approaches. Limnologica 40:251-259.

Pannard A, Bormans M, Lagadeuc Y, 2008. phytoplankton species turnover controlled by physical forcing at different time scales. Can. J. Fish. Aquat. Sci. 65:47-60.

Reynolds CS, 2006. Phytoplankton periodicity: the interactions of form, function and environmental variability. Freshwater Biol. 14:111-142.

Reynolds CS, Huszar VLM, Kruk C, Naselli-Flores L, Melo S, 2002. Towards a functional classification of the freshwater phytoplankton. J. Plankton Res. 24:417-428.

Rücker J, Wiedner C, Zippel P, 1997. Factors controlling the dominance of Planktothrix agardhii and Limnothrix redekei in eutrophic shallow lakes. Hydrobiologia 342/343:107-115.

Wilk-Woźniak E, Żurek R, 2006. Phytoplankton and its relationships with chemical parameters and zooplanktonin the meromictic Piaseczno reservoir, Southern Poland. Aquat. Ecol. 40: 165-176.

Wissel B, Fry B, 2005. Tracing Mississippi River influences in estuarine food webs of coastal Louisiana. Oecologia 144:659-672.

Salmaso N, Zignin A, 2010. At the extreme of the physical gradients: phytoplankton in the highly flushed, large rivers. Hydrobiologia 639:21-36.

Salmaso N, Naselli-Flores L, Padisák J, 2015. Functional classifications and their application in phytoplankton ecology. Freshwater Biol. 60:603-619.

Smayda TJ, Reynolds CS, 2003. Strategies of marine dinoflagellate survival and some rules of assembly. J. Sea Res. 49:95-106.

Stević F, Mihaljević M, Špoljaric D, 2013. Changes of phytoplankton functional groups in a floodplain lake associated with hydrological perturbations. Hydrobiologia 709:143-158.

Sun J, Liu DY, Qian SB, 1999. Study on phytoplankton biomass I. Phytoplankton measurement biomass from cell volume or plasma volume. Acta Oceanol. Sin. 21:75-85.

Xiao L, Wang T, Hu R, Han B, Wang S, Qian X, Padisák J, 2011. Succession of phytoplankton functional groups regulated by monsoonal hydrology in a large canyon-shaped reservoir. Water Res. 45:5009-5019. 